\title{
AKRUAL: Jurnal Akuntansi
}

ISSN (Print) 2085-9643

ISSN (online) 2502-6380

DOI: dx.doi.org/10.26740/jaj

\section{THE INFORMATION OF EDITORIAL POLICIES AKRUAL: JURNAL AKUNTANSI FACULTY OF ECONOMICS UNIVERSITAS NEGERI SURABAYA}

AKRUAL: Jurnal Akuntansi - Journal of Accounting Research with registered number ISSN 2085-9643 (Print) and ISSN 2502-6380 (Online), is a peer-reviewed journal published two times a year (April and October) by Department of Accounting, Faculty of Economics, Universitas Negeri Surabaya and published by Universitas Negeri Surabaya in collaboration Asosiasi Pendidikan Ekonomi-Lembaga Pendidikan Tinggi Kependidikan. The AKRUAL invites manuscripts in the various topics include, but not limited to, financial accounting, management accounting, corporate governance, accounting education, ethics and profesionalism, capital market and bank, auditing, taxes, public sector accounting, sharia accounting and also accounting information system.

\section{GENERAL GUIDE}

1. The article is original guaranteed by the writer and is not published by the other journals/ proceedings.

2. The contribution toward the development of science and technology is from the new findings/ ideas/opinions which prioritize the current primary references at the latest 10 years.

3. The article is an empirical study. The sharpness of critically analysis and synthesis is much prioritized.

4. The review process is conducted in blind review process with the peer group system, which is reinforced by the qualifed reviewers in their feld.

5. The article is writen according to the rule of AKRUAL and an editorial team reserves the right to revise the style of writing with a note that it does not change the intent and quality of the article.

6. Questionnaires and other instruments. Manuscript articles that use primary data research or experimentation must also include the questionnaires.

7. Authors are obliged to send the results of data processing as well as tables and the original image file via email.

8. Articles submited online through https://journal.unesa.ac.id/index.php/aj/index or email address to akrualoffice@gmail.com and equipped with a curriculum vitae, correspondence address, origin of the institution agencies, email and phone number/ mobile phone.

9. Results of the assessment possibilities articles can be:
a Accepted with minor revisions. 
b Accepted with major revisions.

c Suggested sent to another appropriate journal.

d Rejected.

1. The article is well-writen in English. The writing of foreign language is italicized. Typed single space for the abstract, single space for content and single space for references. Writen by font Times New Roman (TNR) 12pt size and indent for paragraphs is $1.5 \mathrm{~cm}$.

2. The paper size is A4 (210 x $297 \mathrm{~mm})$, it is two columns and the page setup is: top margin $3 \mathrm{~cm}$; botom margin $3 \mathrm{~cm}$; left margin $2 \mathrm{~cm}$ and right margin $2 \mathrm{~cm}$.

3. The article will be tested plagiarism with Turnitin (maximum $35 \%$ ).

4. The font size for the title is TNR 12pt, it is capitalized, bolded and lef justifed.

5. Afer the title, it is followed by the author (without the title). It is TNR 11pt, bolded and left justifed.

6. Under the author, it is the institution and the email at TNR 11pt, capitalized each word, without bolded and left justifed. For example: Faculty of Economics, Universitas Negeri Surabaya, Surabaya, Indonesia.

7. The font size for the sub-part in the article is TNR 11pt, capitalized, bolded, and left justifed and without any bullet and numbering.

8. Table.

The table uses a line with a thickness of 1 pt with a 10 or adjusted letter size. The table title is inserted above the table. This also applies to table format. See the example

Table 1. Equation

\begin{tabular}{ccccc}
\hline Variabel & B & Wald & Sig. & Exp. (B) \\
\hline EBITTA & $-19,194$ & 5,898 & 0,001 & 0,000 \\
TDTA & 4,349 & 1,781 & 0,015 & 77,381 \\
C & $-0,278$ & 1,032 & 0,480 & 0,483 \\
\hline
\end{tabular}

Source: Mentioned

9. Figure

Writing the title of fgures and graphics placed under the pictures with lef justifed

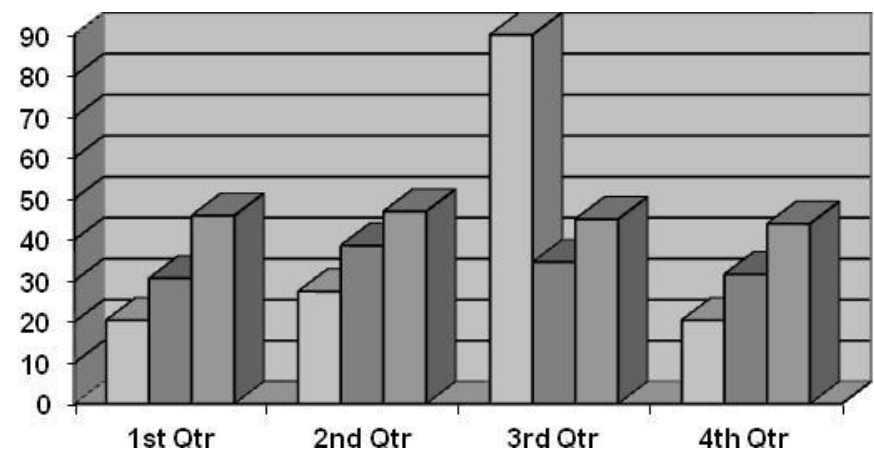

Figure 1. Title 
10. The total page does not exceed 25 pages, including the references and appendices (if any).

\section{B. The Article Systematic}

The article systematic includes: the title, the identity of the author (without a title); abstract; keywords; introduction, literature review, research methods, analysis and discussionand, conclusions, and references. While discussion about literature review and previous studies included in the introduction or result and discussion.

\section{The Article Format}

1. Title. The title must be interesting, specific and informative, which is measured by directness in writing.

2. The author identity. It includes the author's name (without the title), the institution, and the email.

3. Abstract. It is written in 170-200 words, in two languages, Bahasa Indonesia and English. Abstract in English is written first and then abstract in Bahasa Indonesia. The abstract should include the purpose of research, data/object of research, method, result or conclusion.

4. Keywords. The keywords should be written in English. Keywords should be chosen carefully and is able to reflect the concepts/variables contained in the article, with the number of three to six keywords.

5. Introduction. Introduction contains background, urgency, problem rationalization, general problem solving, and research objectives. Article length between 3.0004.000 words, including bibliography, footnotes, figures, and tables.

6. Literature Review. For quantitative research, it is better to present the theoretical framework or previous research review. For qualitative research, it should be discussed regarding the issues raised in the introduction.

7. Research Methods. The research method describes research design, scope or object, material and main tool analysis, place, data collection technique, an operational definition of research variable, and hypothesis (if any).

8. Analysis And Discussion. This section contains data analysis related to research objectives. The discussion focuses on depth discussion and solid argumentation to answer research questions that expose the logic of findings. This section proportion is about $60-80 \%$ of the total length. Use of tables, charts or charts is strongly recommended. Authors are allowed to use tables, figures or charts.

9. Conclusions. The conclusion contains a brief summary of research and concise discussion that answers the research objectives. This section proportion is about 10-15 $\%$ of the total length.

\section{References.}

- References refers to APA Style (American Psychological Association $6^{\text {th }}$ Style)

- Approximately $80 \%$ references include $10-15$ years

- Approximately $80 \%$ primer source (journal article, magazine article, Newspaper Article, Statute, Report, encyclopedia article), and $20 \%$ seconday source (book, web page)

- Use a reference management software like mendeley or endnote 


\section{MANUSCRIPT MANAGEMENT SYSTEM DESIGN OF AKRUAL: JURNAL AKUNTANSI}

\section{SOP of Management in Manuscript}

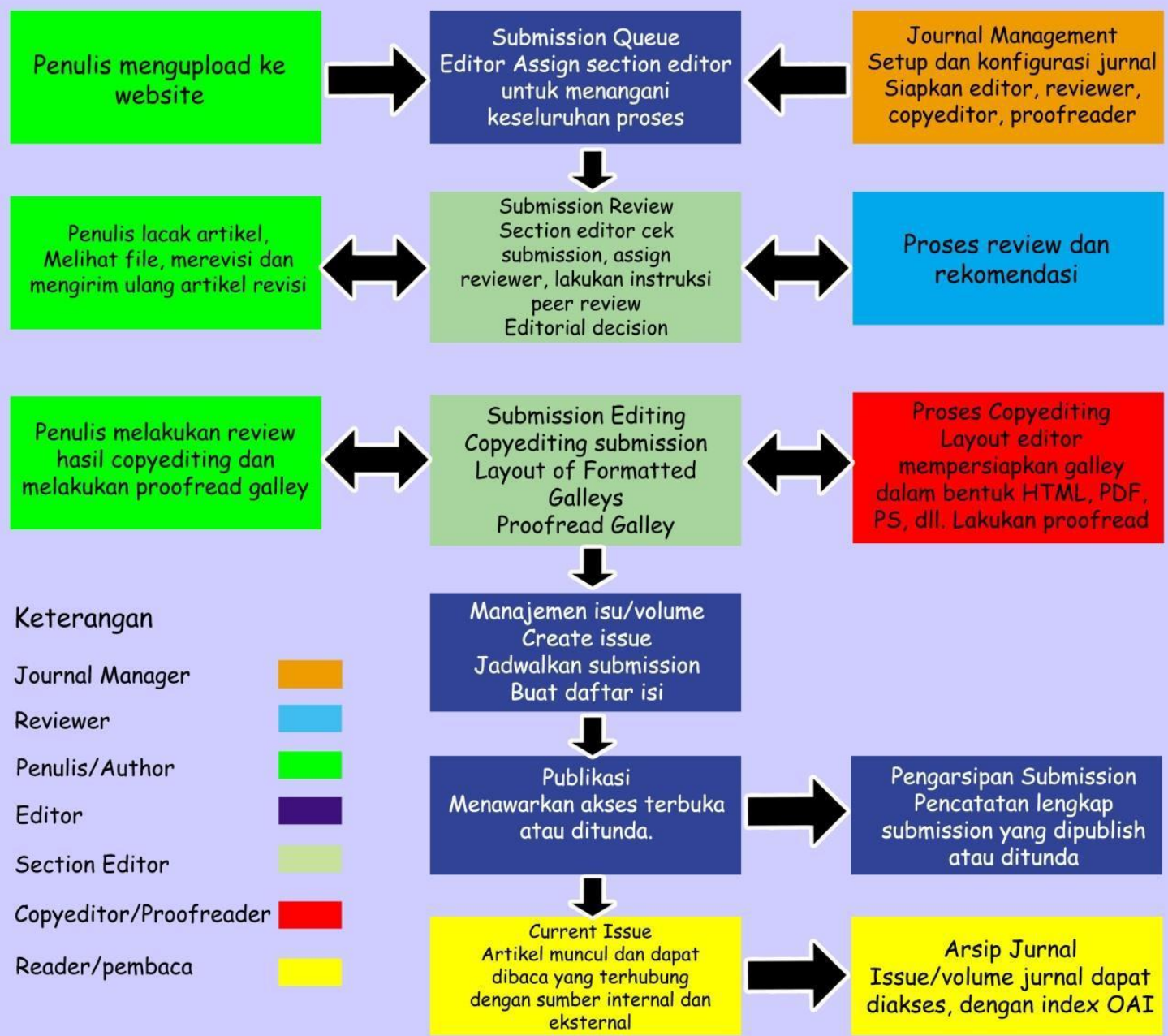

Terminologi:

Galley : seperti dapur yang berfungsi mempersiapkan artikel untuk dipublish dalam format yang direncanakan/ditentukan.

Metadata : informasi terstruktur yang mendeskripsikan, menjelaskan, menemukan, atau setidaknya membuat menjadikan suatu informasi mudah untuk ditemukan kembali, digunakan, atau dikelola. Contoh: nama penulis, judul, tahun, asal universitas.

Submission : proses pengiriman artikel.

Peer review : proses penelaahan artikel oleh reviewer (sejawat, yang memiliki keilmuan yang sama).

i-index : atau i10-index, adalah jumlah yang mengindikasikan publikasi yang dicited per sepuluh kali.

h-index : jumlah publikasi dengan cited terbanyak.

DOI : Digital Object Identifier, memberikan catatan ilmiah atau artikel yang mengenali angka-angka secara unik yang dapat digunakan oleh seseorang untuk menempatkan rincian catatan, dan mungkin salinan elektronik. Unique number/coding untuk sebuah artikel. 


\section{INDEXING AND ABSTRACTING}

AKRUAL: Jurnal Akuntansi indexed by:

1. Directory of Open Access Journal (DOAJ)

2. Google Scholar

3. Academia.edu

4. Indonesian Scientific Journal Database (ISJD) Neo

5. Crossref

6. Indonesia One Search

7. Bielefeld Academic Search Engine (BASE)

8. EBSCO

9. AcademicKeys

10. SINTA (S3)

11. Indonesian Publication Index (IPI)

12. Microsoft Academic Search

13. ROAD (Directory of Open Access Scholarly Resources)

14. Columbia University Libraries

15. Universiteit Leiden

16. Universiteitsbibliotheek Ghent

17. The University of Manchester

18. OpenAIRE

19. SHERPA/ROMEO >>Type in Keyword: Akrual: Jurnal Akuntansi

20. The University of Sheffield

21. GARUDA: Garba Rujukan Digital

22. COPERNICUS

For detail please visit website: https://journal.unesa.ac.id/index.php/aj/pages/view/abs 
AKRUAL: Jurnal Akuntansi

ISSN (Print) 2085-9643

ISSN (online)2502-6380

DOI: dx.doi.org/10.26740/jaj

\section{ETHICS \& MALPRACTICE STATEMENT}

\section{Publication Ethics}

Statement of professional ethical codes is a statement of the ethical codes of all parties involved in the process of publication of this scientific journal (Editors, Peer-reviewers, and Authors). In general, the publication ethics of the AKRUAL: Jurnal Akuntansi refers to the Committee on Publication Ethics (COPE) about Best Practice Guidelines for Journal Editor and Peraturan Kepala LIPI Nomor 5 Tahun 2014 about the Ethical Codes of Scientific Publication. Essentially, the code of ethics itself upholds three values of ethics in publications, namely:

1. Neutrality (free from conflicts of interest in public management),

2. Justice (giving the right of authorship to the beneficiary as the author), and

3. Honesty (free from duplication, fabrication, falsification, and plagiarism (DF2P) in the publication.

\section{DUTIES OF EDITORS}

\section{Publication Decisions}

The editor is responsible for deciding which of the articles submitted to the journal should be published. The editor may be guided by the policies of the journal's editorial board and constrained by such legal requirements as shall then be in force regarding libel, copyright infringement and plagiarism. The editor may confer with other editors or reviewers in making this decision.

\section{Fair Play}

An editor at any time evaluate manuscripts for their intellectual content without regard to race, gender, sexual orientation, religious belief, ethnic origin, citizenship, or political philosophy of the authors.

\section{Confidentiality}

The editor and any editorial staff must not disclose any information about a submitted manuscript to anyone other than the corresponding author, reviewers, potential reviewers, other editorial advisers, and the publisher, as appropriate. Disclosure and Conflicts of Interest Unpublished materials disclosed in a submitted manuscript must not be used in an editor's own research without the express written consent of the author.

\section{DUTIES OF REVIEWERS}

\section{Contribution to Editorial Decisions}

Peer review assists the editor in making editorial decisions and through the editorial communications with the author may also assist the author in improving the paper.

\section{Promptness}

Any selected referee who feels unqualified to review the research reported in a manuscript or knows that its prompt review will be impossible should notify the editor and excuse himself from the review process. 


\section{Confidentiality}

Any manuscripts received for review must be treated as confidential documents. They must not be shown to or discussed with others except as authorized by the editor.

\section{Standards of Objectivity}

Reviews should be conducted objectively. Personal criticism of the author is inappropriate. Referees should express their views clearly with supporting arguments.

\section{Acknowledgement of Sources}

Reviewers should identify relevant published work that has not been cited by the authors. Any statement that an observation, derivation, or argument had been previously reported should be accompanied by the relevant citation. A reviewer should also call to the editor's attention any substantial similarity or overlap between the manuscript under consideration and any other published paper of which they have personal knowledge.

Disclosure and Conflict of Interest

Privileged information or ideas obtained through peer review must be kept confidential and not used for personal advantage. Reviewers should not consider manuscripts in which they have conflicts of interest resulting from competitive, collaborative, or other relationships or connections with any of the authors, companies, or institutions connected to the papers.

\section{DUTIES OF AUTHORS}

\section{Reporting Standards}

Authors of reports of original research should present an accurate account of the work performed as well as an objective discussion of its significance. Underlying data should be represented accurately in the paper. A paper should contain sufficient detail and references to permit others to replicate the work. Fraudulent or knowingly inaccurate statements constitute unethical behavior and are unacceptable.

\section{Originality and Plagiarism}

The authors should ensure that they have written entirely original works, and if the authors have used the work and/or words of others that this has been appropriately cited or quoted.

\section{Multiple, Redundant, or Concurrent Publication}

An author should not in general publish manuscripts describing essentially the same research in more than one journal or primary publication. Submitting the same manuscript to more than one journal concurrently constitutes unethical publishing behaviour and is unacceptable.

\section{Acknowledgement of Sources}

Proper acknowledgment of the work of others must always be given. Authors should cite publications that have been influential in determining the nature of the reported work.

Authorship of the Paper

Authorship should be limited to those who have made a significant contribution to the conception, design, execution, or interpretation of the reported study. All those who have made significant contributions should be listed as co-authors. Where there are others who have participated in certain substantive aspects of the research project, they should be acknowledged or listed as contributors.The corresponding author should ensure that all appropriate co-authors and no inappropriate co-authors are included on the paper, and that all co-authors have seen and approved the final version of the paper and have agreed to its submission for publication.

Disclosure and Conflicts of Interest

All authors should disclose in their manuscript any financial or other substantive conflict of interest that might be construed to influence the results or interpretation of their manuscript. All sources of 
financial support for the project should be disclosed.

Fundamental Errors in Published Works

When an author discovers a significant error or inaccuracy in his/her own published work, it is the author's obligation to promptly notify the journal editor or publisher and cooperate with the editor to retract or correct the paper.

\section{ACKNOWLEDGMENT TO REVIEWERS}

Contribution from the following Reviewers in this issue was very appreciated:

1 Prof. Imam Ghazali, M.Com, Ph.D,

2 Dr. Dian Anita Nuswantara, Ak, M.Si,

3 Drs. Heri Yanto, MBA, PhD,

4 Dr. Hariyati, Ak, M.Si, CA,

5 Dr. Tarjo, SE, M.Si, CFE,

6 Dr. Rohmawati Kusumaningtias, SE, Ak, MSA, CA

7 Dr. Tettet Fitrijanti, M.Si., Ak., CA,

8 Dr. Pujiono, SE, Ak, M.Si,

9 Dra. Y. Anni Aryani, M.Prof.Acc., Ph.D,

10 Taufiq Arifin, SE, M.Sc, Ak, CA,
[SCOPUS ID: 55875276500] Departement of Accounting, Faculty of Economics and Business, Universitas Diponegoro, Indonesia [SCOPUS ID: 57200395873] Departement of Accounting, Faculty of Economics, Universitas Negeri Surabaya, Indonesia [SCOPUS ID: 57191187793] Departement of Accounting, Faculty of Economics and Business, Universitas Negeri Semarang, Indonesia Departement of Accounting, Faculty of Economics,

Universitas Negeri Surabaya,, Indonesia

Departement of Accounting, Faculty of Economics and Business, Universitas Trunojoyo Madura, Indonesia

Departement of Accounting,

Faculty of Economics,

Universitas Negeri Surabaya, Indonesia [SCOPUS ID: 57189266572] Departement of Accounting. Faculty of Economics and Business, Universitas Padjajaran, Indonesia

[SCOPUS ID: 57200392519] Department of Accounting, Faculty of Economics, Universitas Negeri Surabaya, Indonesia [SCOPUS ID: 57191042768] Department of Accounting, Faculty of Economics and Business, Universitas Sebelas Maret Surakarta, Indonesia [SCOPUS ID: 56310015200] Department of Accounting, Faculty of Economics and Business, Universitas Sebelas Maret Surakarta, Indonesia 